\section{P-SU-160}

IMPLANT THERAPY

OUTCOMES; SURGICAL ASPECTS

\title{
Clinical evaluation of xenograft in the 57 maxillary sinus augmentation procedures
}

Tárcio Hiroshi Ishimine Skiba DDS. MS; Cláudio Ferreira Nóia DDS. MS. PhD; Bruno Sá DDS. MS; Jamil Awad Shibli DDS. MS. PhD; Tallyta Motta Prado DDS. SOEP/FACSETE, Brazil.

Background and Aim

Background: Subjects with maxillary posterior atrophy present maxillary sinus penumatization that could avoid or difficult dental implant placement. Several biomaterials have been used to reduce morality and autogenous bone availability.

Aim: To evaluate the efficacy of xenograft material from bovine origin (Lumina-Bone Porous $\AA$; Critéria Ind. e Com. de Produtos Medicinais e Odontológicos Ltda., São Carlos, Brazil) in maxillary sinus augmentation procedures.

\section{Methods and Materials}

A total 35 subjects with of 57 maxillary sinus cavities with alveolar bone height lower than $3 \mathrm{~mm}$. The lateral window approach was used to access the maxillary sinus and perform the sinus lifting procedure using solely xenograft material. Six months after augmentation surgery, the ares received dental implants and thereafter the final implant-supported restoration
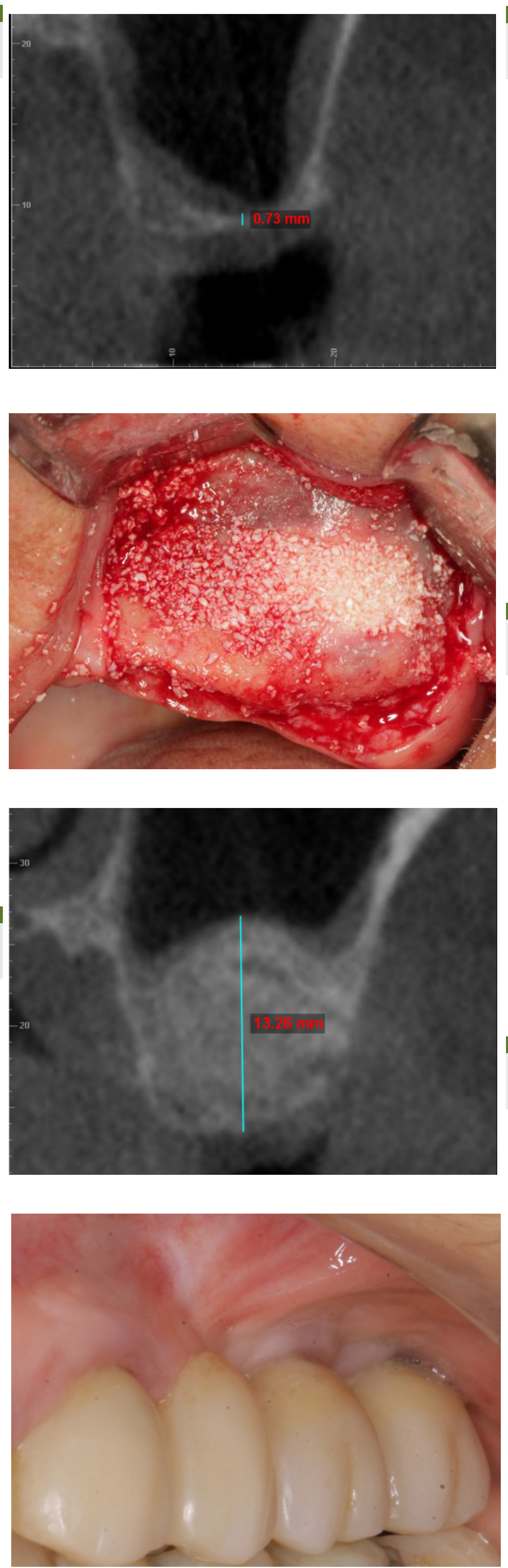

\section{Results}

Radiographic evaluation showed that I 53 out $57(92.9 \%)$ sinus cavities presented sufficient height gain $(>9 \mathrm{~mm})$ to allow dental implant placement. A total of 103 implants were placed and 3 implants presented early lack of osseointegration and 2 implants presented late loss of 2 after 27-month follow-up (95.14\%).

\section{Conclusion}

Within the limits of this clinical study, the biomaterial evaluated proved to be reliable and predictable for implant placement as well as well successfully restored, at least after 27 months period.

\section{References}

1 - Aranha LC, Braga FJCAnálise clínico-cirúrgica comparativa de dois produtos de enxertia óssea, existentes no mercado nacional caracterizados como matriz óssea bovina, tendo como referência uma matriz similar produzida com requisitos específicos. Revista Implantnews. 2011;8(3b-PBA):245-51

2 - Contador GP, Torres CVR, Martini GG, Homen MGN, Nóia CF, Sá BCM. Otimização de resultados através da colocação do Implante Dentário e associação de osso liofilizado e membrana reabsorvível relato de caso. Full Dent. Sci. 2016; 7(26):41-46.

3 - Hans-Dieter J, Wenz B Histomorphometric Analysis of Natura Bone Mineral for Maxillary Sinus Augmentation .INT J ORAL MAXILLOFAC IMPLANTS 2004;19:199-207

4 - Ferreira AJ, Arantes Jr EG, Mata RS, Freitas WA, Sá BCM, Nóia $\mathrm{CF}$. Abordagem cirúrgica para levantamento do soalho do seio maxilar nos casos de presença de septo sinusal. Full Dent. Sci. 2018 9(35):11-16. DOI: 10.24077/2018;935-1116

5 - Skiba THI, Barbosa SA, Moreira MZ, Sá BCM, Nóia CF. Alveolar crest expansion for dental implant insertion: case report. J Braz Coll Oral Maxillofac Surg. 2018 May-Aug;4(2):59-63. DOI: https://doi.org/ 10.14436/2358-2782.4.2.059-063.oar 